\title{
BIBLIOGRAPHY
}

\author{
Archival sources
}

\section{Library and Archives Canada}

Colonial Office (United Kingdom) - Child migration to Canada (LAC) R219109-2-E, Volume RG25-B-1-b 188

Department of Indian Affairs records (LAC) MG29 E106 Volume 12, 16-8, RG10 Volumes 2771, 3674, 3676, 3920, 3930-1, 6001, 6027, 6039-41, 6267-8, $6307,6320,6430,6436,6451-2$

Kelso papers (LAC) MG30 C97 Volumes 1, 2, 4-6, 11, 14-5, 18, 24-7, 34 \& 36, Boxes 11-15, 17, 18, 27, 32-3

\section{Mitchell Library, Sydney}

Aborigines Protection Association, 'The Rightful Owners. Our Duty to Them. Being the Annual Report of the Aborigines Protection Association for 1890' (Sydney, 1891)

New South Wales Aborigines Protection Association, 'Report of the New South Wales Aborigines Protection Association, June 30th 1881' (Sydney, 1881)

\section{Public Records Office, Victoria}

Board for the Protection of Aborigines, Correspondence files, VPRS 1694 P0000 Unit 15

\section{Scots Church, Melbourne Archives}

Reports and financial statements 1883-96

\section{University of Liverpool Archives}

Maria Rye's Emigration Home for Destitute Little Girls, D630

\section{Periodicals}

Advocate 1868-1906

Argus 1870-9

Australasian 1851

Australian Christian World 1890-1912

Australian Herald 1889-1905

Australian Weekly 1894

Australian Witness 1853

Brothers and Sisters 1890-1914

Bubbles 1888-9

Children's Advocate and Christian at Work 1871-87 


\section{BIBLIOGRAPHY}

The Children's Hour from the Children's Home 1889-99

Children's League of Pity Paper 1893-1903

Children's Treasury 1876-80

Child's Guardian 1887-1908

Church of England Messenger 1869-1913

Collingwood Mission Magazine 1907

Contemporary Review 1877-97

Daily Examiner 1893

Examiner 1860-1878

From Dark to Dawn 1895-1915

Highways and Hedges 1880-1914

Home Missions 1890-1908

In Our Midst 1896-1914

London Quarterly Review 1868-91

Mission Notes 1895-6

A Narrative of Facts relative to Work Done for Christ 1872-1914

National Waifs' Magazine 1900-5

New Moral World 1835-6

Night and Day 1877-1914

Once a Week 1861-74

Our Darlings 1881-91

Our Waifs and Strays 1882-1914

Ragged School Union Magazine 1849-59

Referee 1910

Reformatory and Refuge Journal 1864-78

Rescue 1896-1914

Review of Reviews 1890-1905

Spectator 1875-1915

Sunday Magazine 1869

Sydney City Mission Herald 1897-1914

Tasmanian Messenger 1860-66

The Times 1869 and 1910

Toronto Globe 1889-98

Toronto Globe and Mail 2008

Touchstone 1870

Ups and Downs 1897-1904

Victorian Independent 1870-9

War Cry 1883-1915

Young England 1887-91

Young Helpers' League Magazine 1899-1915

Young People's Union 1912 


\section{BIBLIOGRAPHY}

\section{Government publications}

Australian Senate Community Affairs Reference Committee, Lost Innocents: Righting the Record Report on Child Migration (Canberra: Senate Printing Unit, 2001)

Australian Senate Community Affairs Reference Committee, Forgotten Australians: A Report on Australians Who Experienced Institutional or Out-of-Home Care as Children (Canberra: Senate Printing Unit, 2004)

Australian Senate Community Affairs Reference Committee, Protecting Vulnerable Children: A National Challenge (Canberra: Community Affairs References Committee, 2005)

'Coranderrk Aboriginal Station: report of the board appointed to enquire into, and report upon, the present condition and management of the Coranderrk Aboriginal Station, together with minutes of evidence', VPP, 1882-3, vol. II (Melbourne: Victorian Legislative Assembly, 1882)

Department of Indian Affairs, The Indian Affairs, Province of Canada. Report for the Half-Year Ended 30th June, 1864 (Quebec: Hunter, Rose and Co., 1864)

Department of Indian Affairs, Report of the Indian Branch of the Department of the Secretary of State for the Provinces (Ottawa: I. B. Taylor, 1872)

Department of Indian Affairs, Annual Report of the Department of the Interior for the Year Ended 30th June, 1874 (Ottawa: 1875)

Department of Indian Affairs, Report of the Deputy Superintendent General of Indian Affairs (Ottawa: 1877)

Department of Indian Affairs, Annual Report of the Department of Indian Affairs for the Year Ended 31st December 1881 (Ottawa: Indian and Northern Affairs Canada, 1881)

Dominion of Canada, Annual Report of the Department of Indian Affairs for the Year Ended 31st December, 1880 (Ottawa: Indian and Northern Affairs Canada, 1880)

'Eleventh report of the Board for the Protection of the Aborigines' in VPP 1875-6, vol. II (Melbourne: Victorian Legislative Assembly, 1876)

'Fifth report of the Central Board appointed to watch over the interests of the Aborigines in the Colony of Victoria', in VPP 1866, vol. II (Melbourne: Victorian Legislative Assembly, 1866)

'First report of the Central Board appointed to watch over the interests of the Aborigines in the Colony of Victoria', in VPP 1861-2, vol. III (Melbourne: Victorian Legislative Assembly, 1862)

Forde, Leneene, Report of the Commission of Inquiry into Abuse of Children in Queensland Institutions (Brisbane: The Inquiry, 1999)

'Fourth report of the Central Board appointed to watch over the interests of the Aborigines in the colony of Victoria', in VPP 1864-5, vol. III (Melbourne: Victorian Legislative Assembly, 1864)

Health Committee, House of Commons, The Welfare of Former British Child Migrants (House of Commons, 1998)

Human Rights and Equal Opportunities Commission, Bringing Them Home: Report of the National Inquiry into the Separation of Aboriginal and Torres 


\section{BIBLIOGRAPHY}

Strait Islander Children from Their Families (Sydney: HREOC, 1997)

Law Commission of Canada, Restoring Dignity: Responding to Child Abuse in Canadian Institutions (Ottawa: Ministry of Public Works and Government Services, 2000)

Mullighan, E.P., Children in State Care: Commission of Enquiry: Allegations of Sexual Abuse and Death from Criminal Conduct (Adelaide: South Australian Parliament, 2008)

'Ninth report of the Board for the Protection of the Aborigines in the Colony of Victoria', in VPP 1873, vol. III (Melbourne: Victorian Legislative Assembly, 1873)

Ombudsman Tasmania, Reviews of Claims of Abuse from Adults in State Care as Children: Final Report Phase 2 (Hobart: Office of the Ombudsman, 2006)

'Report of the Board for Protection of the Aborigines', in NSWPP (Sydney: New South Wales Legislative Assembly, 1883-4)

'Report of the Board for Protection of Aborigines for 1889' (Sydney: New South Wales Legislative Assembly, 1890)

'Report of the Board for Protection of Aborigines for the year 1905', NSWPP 1907, vol. 2 (Sydney: New South Wales Legislative Assembly, 1907)

'Report of the Board for the Protection of Aborigines for the year 1906', in NSWPP 1907, vol. 2 (Sydney: New South Wales Legislative Assembly, 1907)

'Report of the Board for the Protection of Aborigines for the year 1907', in NSWPP 1908, vol. 2 (Sydney: New South Wales Legislative Assembly, 1908)

'Report of the Board for the Protection of Aborigines for the year 1910', in NSWPP 1911-12, vol. 2 (Sydney: New South Wales Legislative Assembly, 1911)

'Report of the Board for the Protection of Aborigines for the year 1914', in NSWPP 1915-16, vol. 1 (Sydney: New South Wales Legislative Assembly, 1915)

'Royal Commission on the Aborigines: report of the commissioners appointed to inquire into the present condition of the Aborigines of this colony, and to advise as to the best means of caring for, and dealing with them, in the future; together with the minutes of evidence and appendices', in VPP 1877-8, vol. III (Melbourne: Victorian Legislative Assembly, 1878)

'Sixth report of the Central Board appointed to watch over the interests of the Aborigines in the Colony of Victoria', in VPP 1869, vol. IV (Melbourne: Victorian Legislative Assembly, 1869)

'Thirty-seventh report of the Board for the Protection of the Aborigines', in VPP 1901, vol. III (Melbourne: Victorian Legislative Assembly, 1901)

'Thirty-sixth report of the Board for the Protection of the Aborigines', in VPP 1900, vol. III (Melbourne: Victorian Legislative Assembly, 1900)

'Twentieth report of the Board for the Protection of the Aborigines in the colony of Victoria', in VPP 1884, vol. IV (Melbourne: Victorian Legislative Assembly, 1884)

'Twenty-fourth report of the Board for the Protection of the Aborigines in the colony of Victoria', in VPP 1888, vol. III (Melbourne: Victorian Legislative Assembly, 1888) 


\section{BIBLIOGRAPHY}

\section{Literature for children and young adults}

An MA of 'Cambridge', English History in Rhyme (Manchester: John Heywood, 1873?)

Anon., A Missionary Present about the Red Children (London: Wesleyan Missionary Society, c. 1872)

Ballantyne, R.M., The Coral Island (London and Melbourne: Thomas Nelson, 19?)

Ballantyne, R.M., Dusty Diamonds Cut and Polished: A Story of City Arab Life and Adventure (Project Gutenberg Ebook \#21729, 2007)

Burnett, Frances Hodgson, A Little Princess (Harmondsworth: Penguin, 1961)

Chalarimeri, Ambrose Mungala, The Man from the Sunrise Side (Broome: Magabala Books, 2001)

Cody, H.A., On Trail and Rapid By Dog-sled and Canoe. The Story of Bishop Bompas's Life Amongst the Red Indians and Eskimos. Told for Boys and Girls (Toronto: The Musson Book Co., 1911)

Everett-Green, Evelyn, Our Winnie and The Little Match-Girl (London: John F. Shaw and Co., 1904)

Farrar, Evelyn, Every Day (London: Religious Tract Society, 1888)

Gunn, Mrs Aeneas, The Little Black Princess (Sydney: Robertson and Mullens, 1948)

Hutchinson, J.R., Hal Hungerford: or, the Strange Adventures of a Boy Emigrant (London: Blackie, 1905)

Jack, Agness (ed.), Behind Closed Doors: Stories from the Kamloops Indian Residential School (Kamloops, Canada: Secwepemc Cultural Education Society, 2000)

Johnson, J., Dibs: A Story of Young London Life (London: Religious Tract Society, n.d.)

Johnstone, C.L., The Young Emigrants: A Story for Boys (London: Thomas Nelson, 1898)

Le Feuvre, Amy, Us, and Our Empire: A Sequel To 'Us, and Our Donkey' (London: Religious Tract Society, 1911)

Lockyer, Betty, 'War baby' in Holding Up the Sky. Aboriginal Women Speak (Broome: Magabala Books, 1999), pp. 26-56

Marchant, Bessie, Black Cockatoo: A Story of Western Australia (London: The Religious Tract Society, 1910)

Olsen, Sylvia with Morris, Rita and Sam, Ann, No Time to Say Goodbye: Children's Stories of Kuper Island Residential School (Victoria, BC: Sono Nis Press, 2001)

Saxby, Argyll, The Call of Honour: A Tale of Adventure in the Canadian Prairies (London: S.W. Partridge and Co. Ltd, 1912)

Spillman, David and Wilyuka, Lisa, Us Mob Walawurru (Broome: Magabala Books, 2006)

Sterling, Shirley, My Name is Seepeetza. (Toronto: Douglas and McIntyre,1992)

Stevenson, Robert Louis, A Child's Garden of Verses (Harmondsworth: Puffin, 1986)

Stretton, Hesba, Lost Gip (London: Religious Tract Society, n.d.) 


\section{BIBLIOGRAPHY}

Thomas, Leslie, This Time Next Week (London: The Companion Book Club, 1964)

Waugh, Benjamin, 'Come, Ye Children': Heart Stories for the Young (London: Cassell and Co., 1889)

Wilkins, Rev. W. J., Harry's Trip to India (London: The Religious Tract Society, n.d.)

\section{Other sources}

Aboriginal Legal Service of Western Australia, Telling Our Story: A Report on the Removal of Aboriginal Children in Western Australia (Perth: Aboriginal Legal Service of Western Australia, 1995)

Aborigines Protection Association, The Rightful Owners. Our Duty to Them. Being the Annual Report of the New South Wales Aborigines Protection Association for 1890 (Sydney: F.S. Dyer \& Co., 1891)

Aborigines Protection Association, The Heathen at Our Doors. Being the Annual Report of the New South Wales Aborigines Protection Association for 1893 (Sydney: F.S. Dyer \& Co., 1894)

Allen, Anne and Morton, Arthur, This Is Your Child: The Story of the National Society for the Prevention of Cruelty to Children (London: Routledge and Kegan Paul, 1961)

Avery, Gillian, 'Children's books and social history' in Selma Richardson (ed.), Research About Nineteenth-Century Children and Their Books (Urbana, IL: University of Illinois Press, 1980)

Barbalet, Margaret, Far from a Low Gutter Girl: The Forgotten World of State Wards: South Australia 1887-1940 (Melbourne: Oxford University Press, 1983)

Barman, Jean, 'Schooled for inequality: the education of British Columbia Aboriginal children' in Nancy Janovicek and Joy Parr (eds), Histories of Canadian Children and Youth (Ontario: Oxford University Press, 2003)

Barnardo, T.J., The 1/- Baby: An Incident of the London Slave Trade (London: Dr Barnardo's Homes, 1889)

Barnhart, William C., 'Evangelicalism, masculinity and the making of imperial missionaries in Late Georgian Britain, 1795-1820', The Historian, 67:4 (2005), 712-32

Barritt, Gordon E., Thomas Bowman Stephenson (Peterborough: Foundery Press, 1996)

Behlmer, George, 'Waugh, Benjamin (1839-1908)', in Oxford Dictionary of National Biography (2004), www.oxfordnb.com/view/article/36787

Behlmer, George K., Child Abuse and Moral Reform in England, 1870-1908 (Stanford: Stanford University Press, 1982)

Bellingham, Bruce, 'Institution and family: an alternative view of nineteenthcentury child saving', Social Problems, 33:6 (1986), S33-S57

Bellingham, Bruce, 'Waifs and strays: child abandonment, foster care, and families in mid-nineteenth-century New York', in P. Mandler (ed.), The Uses of Charity: The Poor on Relief in the Nineteenth-Century Metropolis (Philadelphia: University of Pennsylvania Press, 1990) 


\section{BIBLIOGRAPHY}

Bixler, Phyllis, 'Idealisation of the child and childhood in Frances Hodgson Burnett's Little Lord Fauntleroy and Mark Twain's Tom Sawyer' in Selma Richardson (ed.), Research About Nineteenth-Century Children and Their Books (Urbana, IL: University of Illinois Press, 1979), pp. 85-96

Bollinger, Maureen, Children of Stainsbridge House (Normanville, South Australia: Maureen Bollinger, 2006)

Brace, Charles Loring, Home Life in Germany (New York: Charles Scribner, 1853) Brade, Cassandra, 'Have we really come that far? Child welfare legislation in Ontario', OACAS Journal, 51: 4 (2007), 7-12

Bradford, Clare, 'Fading to black: Aboriginal children in colonial texts', Papers: Explorations into Children's Literature, 9: 1 (1999), 14-30

Brantlinger, Patrick, Rule of Darkness: British Literature and Imperialism, 1830-1914 (Ithaca and London: Cornell University Press, 1988)

Bratton, Jacqueline, The Impact of Victorian Children's Fiction (London: Croom Helm, 1981)

Breckinridge, Sophia, 'Neglected widowhood in the Juvenile Court', American Journal of Sociology, 16: 1 (1910), 53-87

Bressey, Caroline, 'Forgotten histories: three stories of black girls from Barnardo's Victorian archive', Women's History Review, 11:3 (2002), 351-74

Brown, Pamela, The Captured World: The Child and Childhood in NineteenthCentury Women's Writings in England (New York: Harvester / Wheatsheaf, 1993)

Bryant, John, There Was a Man Whose Name Was John: An Autobiography (Perth: John Bryant, 1982)

Canning, Kathleen, 'Feminist history after the linguistic turn: historicizing discourse and experience', Signs, 19: 2 (1994), 368-404

Carpenter, Humphrey and Prichard, Mari, The Oxford Companion to Children's Literature (Oxford: Oxford University Press, 1984)

Castle, Kathryn, Britannia's Children: Reading Colonialism through Children's Books and Magazines (Manchester and New York: Manchester University Press, 1996)

Chen, Xiaobei, "Cultivating children as you would valuable plants": the gardening governmentality of child saving, Toronto, Canada, 1880s-1920s'. Journal of Historical Sociology, 16: 4 (2003), 460-86

Childers, Joseph W., 'Observation and representation: Mr. Chadwick writes the poor', Victorian Studies, 37: 3 (1994), 405-31

The Church of England Central Home for Waifs and Strays, First Annual Report (London: Church of England Central Home for Waifs and Strays, 1882)

Church of England Central Society for Providing Homes for Waifs and Strays, Sixth Annual Report for the Year Ended March 31st, 1887 (London: Church of England, 1887)

Collie-Holmes, Mary, Where the Heart Is: A History of Barnardo's New Zealand 1866-1991 (Barnardo's: New Zealand, 1991)

Constantine, Stephen, 'Children as ancestors: child migrants and identity in Canada', British Journal of Canadian Studies, 16 (2003), 150-9

Coppleman, Frederick A., Not of My Choice (West Tamar, Tasmania: F.A. Coppleman, 1994) 


\section{BIBLIOGRAPHY}

Corbett, Gail H., Nation Builders: Barnardo Children in Canada (Toronto: Dundurn Press, 2002)

Coveney, Peter, The Image of Childhood: The Individual and Society: A Study of the Theme in English Literature (London: Penguin, 1967)

Coverdale, Douglas, 'It All Turns out for the Better': One Man's Story of His Time in an Australian Boys' Home, 1928-1935, and His Life Thereafter (Melbourne, Victoria: Action Research Issues Association, 1995)

Cox, Jeffrey, 'Master narratives of imperial missions', in Gareth Griffiths and Jamie S. Scott (eds), Mixed Messages: Materiality, Textuality, Missions (New York: Palgrave Macmillan, 2005)

Cunningham, Hugh, The Children of the Poor: Representations of Childhood since the Seventeenth Century (Oxford: Blackwell, 1991)

Cutt, Margaret Nancy, Ministering Angels (Broxbourne, Herts: Five Owls Press, 1979|

Davey, Cyril, A Man for All Children: The Story of Thomas Bowman Stephenson (London: Epworth Press, 1968)

Davies, Kate, When Innocence Trembles: The Christian Brothers Orphanage Tragedy (Sydney: Angus and Robertson / Harper Collins, 1994)

Davin, Anna, 'Waif stories in late nineteenth-century England', History Workshop Journal, 52 (2001), 67-98

Edwards, Coral and Read, Peter, The Lost Children: Thirteen Australians Taken from Their Aboriginal Families Tell of the Struggle to Find Their Natural Parents (Moorebank, NSW: Doubleday, 1989)

Edwards, Susan, 'Discourses of denial and moral panics: the pornographisation of the child in art, the written word, film and photograph', in Judith Rowbotham and Kim Stevenson (eds), Behaving Badly: Social Panic and Moral Outrage - Victorian and Modern Parallels (Aldershot: Ashgate, 2003)

Eekelaar, John "The chief glory": the export of children from the United Kingdom', Journal of Law and Society, 21: 4 (1994), 487-504

Engel, Monroe, 'The politics of Dickens' novels', PMLA, 71: 5 (1956), 945-74

Felshin, Nina, 'Clothing as subject', Art Journal, 54: 1 (1995), 20-9

Ferguson, Harry, 'Abused and looked after children as "moral dirt": child abuse and institutional care in historical perspective', Journal of Social Policy, 36: 1 (2007), 123-39

Flegel, Monica, 'Changing faces: the NSPCC and the use of photography in the construction of cruelty to children', Victorian Periodical Review, 39: 1 (2006), 1-20

Frankenberg, Ruth (ed.), White Women, Race Matters: The Social Construction of Whiteness (Minneapolis: University of Minnesota Press, 1993)

Frankenberg, Ruth (ed.), Displacing Whiteness: Essays in Social and Cultural Criticism (Durham, NC: Duke University Press, 1997)

Garlitz, Barbara, 'Christina Rossetti's Sing-Song and nineteenth-century children's poetry', PMLA, 70: 3 (1955), 539-43

Garton, Stephen, 'Asylum histories: reconsidering Australia's lunatic past', in Catharine Coleborne and Dolly MacKinnon (eds), 'Madness' in Australia: Histories, Heritage and the Asylum (St Lucia: University of Queensland Press, 2003) 


\section{BIBLIOGRAPHY}

'Germany: annual meeting of the Evangelical Church at Elberfeld in 1851: second notice', Evangelical Christendom: Its State and Prospects VI (1852), 139-49

'Germany: the juvenile reformatory institution at the Rough House, Horn, near Hamburgh [sic]', Evangelical Christendom: Its State and Prospects VI (1852), 174-6

Gill, Alan, Orphans of the Empire: The Shocking Story of Child Migration to Australia (Alexandria, NSW: Millennium Books, 1997)

Gilliver, John, 'Religious values and children's fiction', Children's Literature in Education, 17: 4 (1986), 215-25

Gish, Clay 'Rescuing the "waifs and strays" of the city: the western emigration program of the Children's Aid Society', Journal of Social History, 33: 1 (1999), 121-31

Greenwood, James, The Little Ragamuffins or, Outcast London. A Story of the Sorrows and Sufferings of the Poor (London: Ward Lock, n.d.)

Hacsi, Timothy, Second Home: Orphan Asylums and Poor Families in America (Cambridge, MA: Harvard University Press, 1997)

Hall, Catherine, White, Male and Middle-Class: Explorations in Feminism and History (Cambridge: Polity, 1992)

Hall, Catherine, 'Going a-trolloping: imperial man travels the empire', in Clare Midgley (ed.), Gender and Imperialism (Manchester: Manchester University Press, 19981

Hall, Catherine, Civilising Subjects: Metropole and Colony in the English Imagination 1830-1867 (Cambridge: Polity, 2002)

Hall, Catherine, 'Of gender and empire: reflections on the nineteenth century', in Philippa Levine (ed.), Gender and Empire (Oxford: Oxford University Press, 2004)

Harrison, Phyllis, The Home Children: Their Personal Stories (Winnipeg: Watson \& Dwyer, 1979)

Hegarty, Ruth, Is That You Ruthie? (St Lucia: University of Queensland Press, 1999|

Henderson, C.R., 'The German inner mission. II. The experimental stage', American Journal of Sociology, 1: 6 (1896), 674-84

Hendrick, Harry, Child Welfare: England, 1872-1989 (London: Routledge, 1994)

Hill, David, The Forgotten Children: Fairbridge Farm School and Its Betrayal of Australia's Child Emigrants (North Sydney, NSW: Random House, 2007)

Hobhouse, Rosa J.P., Benjamin Waugh: Founder of the National Society for Prevention of Cruelty to Children (London: The C.W. Daniel Co. Ltd, 1939)

Hofmeyr, Isabel, 'Inventing the world: transnationalism, transmission and Christian textualities', in Gareth Griffiths and Jamie S. Scott (eds), Mixed Messages: Materiality, Textuality, Missions (New York: Palgrave Macmillan, 2005)

Holland, Patricia, What is a Child?: Popular Images of Childhood (London: Virago, 1992)

Hopkins, Eric, Childhood Transformed: Working-Class Children in Nineteenth- 


\section{BIBLIOGRAPHY}

Century England (Manchester and New York: Manchester University Press, 1994)

Hourihan, Margery, Deconstructing the Hero: Literary Theory and Children's Literature (London: Routledge, 1997)

Howard, Ann and Leonard, Eric, After Barnardo: The Phenomenon of Child Migration from Tilbury to Sydney from 1921-1965 (Dangar Island, NSW: Tarka Publishing, 1999)

Hurst, John F., History of Rationalism (London: Trubner and Co., 1867)

Jacobsen, Walter, Dussa and the Maiden's Prayer (Melbourne: Victoria Press, 1994)

Jaffe, Audrey, 'Spectacular sympathy: visuality and ideology in Dickens's $A$ Christmas Carol', PMLA, 109: 2 (1994), 254-65

Kahan, Barbara, Growing Up in Care: Ten People Talking (Oxford: Blackwell, 1979)

Kartinyeri, Doris, Kick the Tin (Melbourne: Spinifex Press, 2000)

Kelso, J.J., The Children's Court: An Outline of the Work It Is Intended to Accomplish (Toronto, 1893)

Kingsley, Charles, 'The massacre of the innocents', in The Works 1880-1885 Vol. XVIII. Sanitary and Social Lectures and Essays (Hildesheim, Germany: Georg Olms Verlags Buchhandlung, 1969)

Kohli, Marjorie, The Golden Bridge: Young Immigrants to Canada, 1833-1939 (Toronto: Natural Heritage Books, 2003)

Koven, Seth, 'Dr Barnardo's "artistic fictions": photography, sexuality, and the ragged child in Victorian London', Radical History Review, 69 (1997), 6-45

Koven, Seth, Slumming: Sexual and Social Politics in Victorian London (Princeton: Princeton University Press, 2004)

Kutzer, Daphne M., Empire's Children: Empire and Imperialism in Classic British Children's Books (London: Routledge, 2000)

Lane, John, Fairbridge Kid (Fremantle Arts Centre Press: Fremantle, 1990)

Lehmann, Hartmut, 'Pietism and nationalism: the relationship between Protestant revivalism and national renewal in nineteenth-century Germany', Church History, 51: 1 (1982), 39-53

Macintyre, Ewan, 'The historical context of child welfare in Canada', in Brian Wharf (ed.), Rethinking Child Welfare in Canada (Toronto: McClelland \& Stewart Inc., 1993)

Mafi-Williams, Lorraine (ed.), Spirit Song: A Collection of Aboriginal Poetry (Norwood, South Australia: Omnibus Books, 1993)

Magnusson, Anna, The Quarriers Story: One Man's Vision that Gave 7,000 Children a New Life in Canada (Toronto: Dundern Press, 2006)

Mahood, Linda and Littlewood, Barbara, "The "vicious girl" and the "streetcorner" boy: sexuality and the gendered delinquent in the Scottish childsaving movement, 1850-1940', Journal of the History of Sexuality, 4 (1994), 549-78

'Maria Charlesworth', in Lorna Sage, Germaine Greer and Elaine Showalter (eds), The Cambridge Guide to Women's Writing in English (Cambridge: Cambridge University Press, 1999)

McDonald, Helen, 'Perish the thought: populating White Australia and the 


\section{BIBLIOGRAPHY}

role of child removal policies', Journal of Australian Studies, 91 (2007), 1-7

McHoul, Alec, 'Taking the children: some reflections at a distance on the camera and Dr Barnardo', Continuum: The Australian Journal of Media and Culture, 5: 1 (1991), 33-50

McNeil, Doug, Order of Things (Bentleigh, Victoria: Doug McNeil, 1995)

Milloy, John, A National Crime: The Canadian government and the Residential Schools System, 1879-1986 (Winnipeg: University of Manitoba Press, 1999)

Moore, Allan, Growing up with Barnardo's (Sydney: Hale and Iremonger, 1990)

Murdoch, Lydia, Imagined Orphans: Poor Families, Child Welfare and Contested Citizenship in London (New Brunswick: Rutgers University Press, 2006)

New South Wales Aborigines Protection Association, Report of the New South Wales Aborigines Protection Association, June 30th 1881 (Sydney: Jarrett \& Co., 1881)

New South Wales Aborigines Protection Association, New South Wales Aborigines Protection Association Report (Sydney, 1883)

Nord, Deborah Epstein, 'The social explorer as anthropologist: Victorian travellers among the urban poor', in William Sharpe and Leonard Wallock (eds), Visions of the Modern City: Essays in History, Art and Literature (Baltimore: Johns Hopkins University Press, 1987)

Norman, Frank, Banana Boy (London: Hogarth, 1987)

O'Connor, Stephen, Orphan Trains: The Story of Charles Loring Brace and the Children he Saved and Failed (Boston: Houghton Mifflin Company, 2001)

O'Dell, Lindsay, 'Representations of the "damaged child": "child saving" in a British children's charity ad campaign', Children and Society, 22 (2008), 383-92

O'Malley, Andrew, The Making of the Modern Child: Children's Literature and Childhood in the Late Eighteenth Century (London and New York: Routledge, 2003)

Parr, Joy, Labouring Children: British Immigrant Apprentices to Canada, 1879-1924 (London: Croom Helm, 1980)

Parry, Naomi, "Such a longing": black and white children in welfare in New South Wales and Tasmania, 1880-1940', PhD thesis, University of New South Wales, 2007

Pearce, Lionel, Feathers of a Snow Angel: Memories of a Child in Exile (Fremantle: Fremantle Arts Centre Press, 2002)

Pedersen, Susan, Family, Dependence, and the Origins of the Welfare State: Britain and France, 1914-1945 (Cambridge: Cambridge University Press, 1993)

Penglase, Joanna, Orphans of the Living: Growing up in 'Care' in TwentiethCentury Australia (Fremantle: Curtin University Books, 2005)

Perry, Gillian (ed.), Gender and Art (New Haven: Yale University Press, 1999)

Powell, Rene and Kennedy, Bernadette, Rene Baker File \#28 / E.D.P. (Fremantle: Fremantle Arts Centre Press, 2005)

Report of the Executive Committee of the Church of England Central Society for Providing Homes for Waifs and Strays (London: Church of England, $1885)$ 


\section{BIBLIOGRAPHY}

Richardson, Alan, 'Romanticism and the end of childhood', NineteenthCentury Contexts, 21: 2 (1999), 169-89

Robinson, W. Gordon, Benjamin Waugh (1839-1908) (London: Independent Press, 1961)

Rooke, Patricia and Schnell, R.L., Discarding the Asylum: From Child Rescue to the Welfare State in English-Canada (1800-1950) (Lanham, NY and London: University Press of America, 1983)

Rose, June, For the Sake of the Children: Inside Dr. Barnardo's, 120 Years of Caring for Children (London: Hodder and Stoughton, 1987)

Rosenblum, Robert, The Romantic Child from Runge to Sendak (London: Thames and Hudson, 1988)

Rowbotham, Judith, Good Girls Make Good Wives: Guidance for Girls in Victorian Fiction (Oxford: Basil Blackwell, 1989)

Rowbotham, Judith and Stevenson, Kim, 'Causing a sensation: media and legal representations of bad behaviour', in Judith Rowbotham and Kim Stevenson (eds), Behaving Badly: Social Panic and Moral Outrage - Victorian and Modern Parallels (Aldershot: Ashgate, 2003)

Rowbotham, Judith and Stevenson, Kim, 'Introduction', in Judith Rowbotham and Kim Stevenson (eds), Criminal Conversations: Victorian Crimes, Social Panic, and Moral Outrage (Columbus: Ohio State University Press, 2005)

Rudolf, Edward de M., The First Forty Years: A Chronicle of the Church of England Waifs and Strays Society 1881-1920 (London: Church of England Waifs \& Strays Society, Kennington, 1922)

Schaff, Philip, Germany: Its Universities, Theology and Religion (Philadelphia: Lindsay and Blakiston, 1857)

Scott, Dorothy and Swain, Shurlee, Confronting Cruelty: Historical Perspectives on Child Abuse (Carlton: Melbourne University Press, 2002)

Shayler, Kate, The Long Way Home: The Story of a Homes Kid (Milsons Point, NSW: Random House, 2001)

Skocpol, T., Protecting Soldiers and Mothers: The Political Origins of Social Policy in the United States (Cambridge, MA: The Belknap Press of Harvard University Press, 1992)

Songs of the Christian Life and Work, Sung by T. Bowman Stephenson, B.A., of London, England, in Behalf of the Children's Home, London, Edgworth and Gravesend (in England), and Hamilton, Ontario, Canada, with Four Engravings of the Homes, and a Sketch of Their History (Toronto: Samuel Rose, 1877)

Stein, Mike, 'Missing years of abuse in children's homes', Child and Family Social Work, 11 (2006), 11-21

Stemp, Evelyn, Home Kids (Brighton: The Book Guild Ltd, 2003)

Strange, Carolyn, 'Stories of their lives: the historian and the capital case file', in Franca Iacovetta and Wendy Mitchinson (eds), On the Case: Explorations in Social History (Toronto: University of Toronto Press, 1998)

Swain, Shurlee, 'Selina Sutherland: child rescuer', in M. Lake and F. Kelly (eds), Double Time: Women in Victoria - 150 Years (Ringwood: Penguin, 1985)

Szablicki, Ryszard, Orphanage Boy: Through the Eyes of Innocence (Frenchs Forest, NSW: New Holland Publishers, 2007) 


\section{BIBLIOGRAPHY}

Todd, Laura and Midlam, Amanda, A Place Like Home: Growing Up in the School of Industry 1915-1922 (Sydney: Hale \& Iremonger, 1987)

van Krieken, Robert, Children and the State: Social Control and the Formation of Australian Child Welfare (Sydney: Allen and Unwin, 1991)

Wagner, Gillian, Barnardo (London: Weidenfeld and Nicolson, 1979)

Walgar, Monty, Jinangga (Broome: Magabala Books, 1999)

Weddell, Margaret, Child Care Pioneers (London: The Epworth Press, 1958)

'Wesleyan Neglected Children's Aid Society', in Home Missions: Twentieth Report of the Wesleyan Home Missions in Victoria (Melbourne: Wesleyan Home Missions, 1894)

Williamson, David, Ninety - Not Out: A Record of Ninety Years' Child Welfare Work of the Shaftesbury Society and R.S.U. (London: Hodder and Stoughton Ltd, 1934)

Woollacott, Angela, Gender and Empire (New York: Palgrave Macmillan, 2006 